Penelitian

\title{
Lesio Aterosklerosis pada Arteri Iliak Monyet Ekor Panjang sebagai Hewan Model Peripheral Arterial Disease (PAD)
}

\author{
(Atherosclerosis Lesion on The Iliac Artery of Cynomolgus Monkey \\ as an Animal Model for Peripheral Arterial Disease)
}

\author{
Sri Rahmatul Laila', Dewi Apri Astuti ${ }^{2,3}$, Irma H Suparto ${ }^{2,4}$, Ekowati Handharyani ${ }^{2,5}$, Dondin Sajuthi ${ }^{* 2,5}$ \\ ${ }^{1}$ Mahasiswa Pascasarjana Institut Pertanian Bogor, Bogor, Indonesia \\ ${ }^{2}$ Pusat Studi Satwa Primata, Institut Pertanian Bogor, Bogor, Indonesia \\ ${ }^{3}$ Departemen Nutrisi dan Teknologi Pakan, Institut Pertanian Bogor, Bogor, Indonesia \\ ${ }^{4}$ Departemen Kimia, Fakultas Matematika dan Ilmu Pengetahuan Alam, Institut Pertanian Bogor, Bogor, Indonesia \\ ${ }^{5}$ Departemen Klinik, Reproduksi, dan Patologi, Fakultas Kedokteran Hewan, Institut Pertanian Bogor, Bogor, Indonesia \\ *Penulis untuk korespondensi: sajuthi@indo.net.id \\ Diterima 2 Juni 2018, Disetujui 13 September 2018
}

\begin{abstract}
ABSTRAK
Aterosklerosis pada arteri iliak berkaitan dengan kejadian peripheral arterial disease (PAD) pada manusia. Penelitian ini bertujuan untuk menganalisis lesio aterosklerosis pada arteri iliak sebagai salah satu faktor penyebab PAD. Penelitian ini menggunakan sembilan monyet ekor panjang jantan dewasa dari 3 kelompok respons yang diberi pakan aterogenik IPB-1 selama 2 tahun. Arteri common iliak diambil pada saat nekropsi, diproses menjadi slaid histologi dan diwarnai dengan Verhoeff van Giesson (VVG). Keparahan lesio dikategorikan sebagai grade I sampai VI dan dianalisis secara deskriptif. Area lesio ditentukan melalui panjang lamina elastik interna (PLEI), area intima (AI), serta ketebalan maksimum intima (KIM) dan dianalisis dengan ANOVA. Hasil penelitian menunjukkan 55,56\% monyet membentuk lesio plak aterosklerosis (grade IV sampai VI) yang mana mereka berasal dari kelompok intermediet dan hiper-responsif. Kelompok hiper-responsif menunjukkan $\mathrm{Al}$ dan $\mathrm{KMI}$ paling tinggi $\left(0,979 \mathrm{~mm}^{2} ; 0,352 \mathrm{~mm}\right)$ diikuti kelompok intermediet $\left(0,372 \mathrm{~mm}^{2} ; 0,237\right.$ $\mathrm{mm})$ dan kelompok hipo-responsif $\left(0,049 \mathrm{~mm}^{2} ; 0,052 \mathrm{~mm}\right)(\mathrm{P}<0,05)$. Hasil ini menunjukkan semakin tinggi kolesterol plasma, semakin luas area lesio yang terbentuk. Keseluruhan hasil mendukung bahwa monyet yang diberi pakan aterogenik IPB-1 selama 2 tahun mampu membentuk lesio plak aterosklerosis pada arteri common iliak, dan berpotensi sebagai hewan model PAD, kecuali kelompok hipo-responsif.

Kata kunci: Aterosklerosis, monyet ekor panjang, arteri iliak, pakan aterogenik
\end{abstract}

\begin{abstract}
Atherosclerosis of the iliac artery is related to the peripheral arterial disease (PAD). This study was aimed to analyze the atherosclerosis lesion on the iliac artery as one cause of PAD. We used 9 adult male cynomolgus monkeys from 3 groups of cholesterol responses that were fed with IPB-1 atherogenic diet for 2 years. Common iliac arteries ( $\mathrm{ClA}$ ) were collected while necropsy, processed into histological slides, then, stained with Verhoeff van Giesson (VVG). Plaques severity was described as grade I to VI and analyzed descriptively. Plaque extent was described as internal elastic lamina length (IELL), intimal area (IA), and maximum intimal thickness (MXIT) and analyzed using ANOVA. The results showed that $55,56 \%$ of experimental monkeys developed an advanced atherosclerosis (grade IV until VI). The hyper-responsive group showed the highest IA and MXIT at the $\mathrm{CIA}\left(0,979 \mathrm{~mm}^{2} ; 0,352 \mathrm{~mm}\right)$ followed by the intermediate group $\left(0,372 \mathrm{~mm}^{2} ; 0,237 \mathrm{~mm}\right)$ and hypo-responsive group $\left(0,049 \mathrm{~mm}^{2} ; 0,052 \mathrm{~mm}\right)(\mathrm{P}<0,05)$. These assessments showed that the higher plasma cholesterol, the larger the area of the lesion. Finally, all of the results support that monkeys fed with IPB-1 atherogenic diet for 2 years can develop an advanced atherosclerosis lesion at the $\mathrm{CIA}$, and they are potentially used as a PAD animal model, except the hypo-responsive group.
\end{abstract}

Keywords: atherosclerosis, cynomolgus, iliac artery, atherogenic diet 


\section{PENDAHULUAN}

Aterosklerosis adalah kondisi penyempitan dan pengerasan pembuluh arteri berukuran besar dan sedang akibat timbunan lipid yang disertai proses peradangan. Aterosklerosis pada arteri iliak dan arteri femoralis adalah penyebab utama terjadinya peripheral arterial disease (PAD) (Lawall et al., 2016). Penyakit ini menyerang lebih dari 200 juta jiwa di seluruh dunia (Fowkes et al., 2013) dengan kejadian asimptomatik lebih tinggi dibandingkan dengan simptomatik. Gejala utama penyakit ini adalah rasa sakit yang amat sangat pada kaki akibat kondisi iskemia (Criqui \& Aboyans, 2015). Berbagai penelitian tentang PAD masih sangat diperlukan untuk menurunkan kejadian penyakit ini.

Monyet ekor panjang/MEP (Macaca fascicularis) asal Indonesia berpotensi digunakan sebagai hewan model untuk PAD, terutama mengenai kondisi aterosklerosisnya, melalui induksi pakan aterogenik (Shelton et al., 2012). Pusat Studi Satwa Primata IPB telah mengembangkan pakan aterogenik lokal IPB-1 yang dapat menginduksi hiperkolesterolemia pada MEP. Pakan ini mengandung kolesterol yang berasal dari kuning telur, asam lemak jenuh yang berasal dari minyak kelapa dan lemak hewan, asam lemak tidak jenuh yang berasal dari minyak jagung, dan karbohidrat yang berasal dari glukosa (Astuti et al., 2014).

Simionescu \& Sima (2012) menjelaskan pembentukan lesio aterosklerosis berawal dari disfungsi endotel, kemudian garit lemak, ateroma, dan berkembang menjadi fibroateroma sampai membentuk lesio kompleks. Lesio aterosklerosis pada arteri common iliak yang merupakan salah satu penyebab utama PAD pada MEP yang diinduksi pakan aterogenik IPB-1 belum diketahui sehingga tujuan penelitian ini adalah identifikasi respons lesio arteri common iliak terhadap pemberian pakan aterogenik IPB-1 yang merupakan langkah penting dalam pembuatan hewan model PAD. Informasi ini akan dapat membantu para peneliti dalam mempelajari hal-hal terkait dengan PAD.

\section{BAHAN DAN METODE}

\section{Disain}

Dua puluh ekor MEP jantan dewasa dengan bobot badan 4-7 kg yang dipelihara pada kandang individu $(0,6 \times 0,6 \times 0,9 \mathrm{~m})$ di fasilitas hewan PSSP IPB, Bogor. Semua perlakuan sudah disetujui Animal Care and Use Committee (ACUC) PSSP IPB dengan nomor PRC-14-B003. Monyet diberi perlakuan pakan aterogenik IPB-1 sebanyak 180-200 g per ekor per hari yang mengandung kolesterol 0,28-0,29 mg/kal selama dua tahun. Lipid darah, glukosa darah, dan morfometri tubuh diukur setiap bulan. Hasil evaluasi lipid darah selama perlakuan menunjukkan nilai total plasma kolesterol (TPK) yang bervariasi sehingga hewan coba dibagi ke dalam tiga kelompok, yaitu hipo-responsif (rata-rata TPK $<200$ $\mathrm{mg} / \mathrm{dl}$ ), intermediet responsif (rata-rata TPK 200-400 $\mathrm{mg} / \mathrm{dl}$ ), dan hiper-responsif (rata-rata TPK $>400$ $\mathrm{mg} / \mathrm{dl}$ ) (Laila et al., 2018). Total 9 ekor dari 20 ekor MEP kemudian dipilih menggunakan rancangan acak kelompok untuk dinekropsi (3 ekor mewakili tiap kelompok respons).

\section{Nekropsi}

Nekropsi dilakukan dokter hewan sesuai dengan prosedur di Bagian Patologi PSSP, LPPM IPB-Bogor. Monyet dibius menggunakan ketamin 10\% dengan dosis $10-15 \mathrm{mg} / \mathrm{kg}$ BB dan silazin 2\% dengan dosis 0,5 $\mathrm{mg} / \mathrm{kg}$ BB. Setelah itu, hewan dieutanasia menggunakan pentobarbital dengan dosis $150 \mu \mathrm{g} / \mathrm{kg}$ BB. Selagi jantung hewan masih berkontraksi, dilakukan perfusi transkardial dengan $\mathrm{NaCl}$ fisiologis lalu difiksasi dengan paraformaldehid $4 \%$ selama satu jam. Kemudian, arteri common iliak monyet diambil dan disimpan dalam paraformaldehid $4 \%$.

\section{Pemprosesan Jaringan}

Teknik pemprosesan arteri common iliak merujuk pada prosedur di Primate Research Center Wake Forest University School of Medicine, NC-USA. Arteri common iliak dari masing-masing monyet disiapkan menjadi 4 potongan melintang ( 2 kanan dan 2 kiri) secara proporsional dengan ukuran $1,0 \times 0,5 \mathrm{~cm}$. Setiap kelompok respons memiliki total 12 potong arteri. Masing-masing potongan arteri kemudian diblok dalam parafin. Blok tersebut lalu dipotong setebal $5 \mu \mathrm{m}$ untuk diwarnai dengan Varhoeff van Gieson (VVG). Pewarnaan VVG dilakukan untuk mengidentifikasi komponen serabut elastik arteri sehingga dapat dilihat tingkat keparahan dan area lesio (Register et al., 2016). Pewarnaan VVG menghasilkan warna hitam untuk serabut elastik, merah untuk serabut kolagen, dan warna kuning untuk otot polos dan komponen sel yang lain.

\section{Tingkat Keparahan Lesio}

Tingkat keparahan lesio ditentukan melalui protokol American Heart Association (AHA) meliputi grade I-VI (Stary et al., 1994; 1995). Grade I diberikan 
untuk arteri normal, grade II diberikan bila ditemukan garit lemak, grade III diberikan bila sudah terbentuk preateroma. Lesio plak aterosklerosis dimulai dari grade $\mathrm{VI}$ atau dikenal dengan ateroma, grade $\mathrm{V}$ yang berupa fibroateroma, dan grade $\mathrm{VI}$ yang merupakan ateroma kompleks. Tingkat keparahan lesio untuk setiap individu ditentukan dari lesio terparah karena terkait dengan kemunculan gejala klinis kondisi aterosklerosis.

\section{Area Lesio}

Area lesio ditentukan dengan parameter panjang lamina elastik interna (PLEI) sebagai batas antara tunika intima dan media arteri, luas area intima (AI) sebagai akibat adanya akumulasi lipid, sel-sel peradangan, dan otot polos, dan ketebalan maksimum intima (KMI). Rata-rata PLEI, Al, dan KMI dihitung dari semua potongan untuk melihat perubahan di sepanjang arteri common iliak.

\section{Analisis Data}

Tingkat keparahan lesio dianalisis secara deskriptif dan ditampilkan dalam tabel dan gambar. Berbeda dari tingkat keparahan lesio, parameter area lesio berupa data kuantitatif ditentukan menggunakan Image Pro Plus ver 9,1 (Media Cybernetic $^{\circledR}$ USA) dan disampaikan dalam rerata \pm standar error (SE). Perbedaan antarkelompok diuji dengan analisis varian (ANOVA) dan uji lanjut Duncan dengan selang kepercayaan 0,05. Semua analisis dilakukan menggunakan SPSS ver 22.

\section{HASIL \\ Tingkat Keparahan Lesio}

Keparahan lesio aterosklerosis berupa AHA grade pada arteri common iliak hewan coba yang diberi pakan aterogenik IPB-1 selama 2 tahun dapat dilihat pada Tabel 1 dan Gambar 1. Plak aterosklerosis (grade IV-VI) tidak terbentuk pada kelompok yang hipo-responsif. Namun, hewan kelompok hiporesponsif tetap menunjukkan perkembangan awal lesio berupa garit lemak yang ditandai dengan adanya sel-sel busa pada tunika intima (grade II).

Lesio aterosklerosis pada arteri common iliak MEP kelompok intermediet didapatkan lebih ringan dibandingkan dengan kelompok hiper-responsif, satu ekor monyet pada kelompok intermediet masih menunjukkan lesio preateroma (grade III). Lesio ini ditandai dengan munculnya titik-titik nekrosis yang berasal dari sel busa yang telah mati. Akan tetapi, pada kelompok intermediet pun ternyata dapat terbentuk lesio kompleks ateroma yang ditandai dengan terbentuknya kapsula fibrosa yang sudah menipis (grade $\mathrm{VI}$ ).

Tabel 1 AHA grade pada arteri common iliak monyet ekor panjang pada ketiga kategori respons

\begin{tabular}{ccccccc}
\hline \multirow{2}{*}{ No } & ID & Kategori respons & \multicolumn{4}{c}{ AHA Grade } \\
\cline { 4 - 6 } & & Hanan(1) & Kanan(2) & Kiri(1) & Kiri(2) \\
\hline 1 & T3707 & Hipo & II & II & II & I \\
2 & FC8501 & Hipo & II & II & II & II \\
3 & T3278 & Intermediet & III & III & II & I \\
4 & FC9015 & Intermediet & IV & VI & IV & III \\
5 & C2480 & Intermediet & $\mathrm{V}$ & $\mathrm{V}$ & $\mathrm{V}$ & $\mathrm{V}$ \\
6 & $\mathrm{C} 4927$ & Hiper & $\mathrm{V}$ & $\mathrm{V}$ & $\mathrm{V}$ & $\mathrm{V}$ \\
7 & T3536 & Hiper & $\mathrm{V}$ & $\mathrm{IV}$ & $\mathrm{V}$ & $\mathrm{V}$ \\
8 & T3700 & Hiper & $\mathrm{VI}$ & $\mathrm{V}$ & $\mathrm{VI}$ & $\mathrm{V}$ \\
\hline
\end{tabular}

Tabel 2 Area lesio pada common iliak arteri pada ketiga kelompok respons

\begin{tabular}{cccc}
\hline Peubah & Hipo-responsif & Intermediet-responsif & Hiper-responsif \\
\hline PLEI $(\mathrm{mm})$ & $6,243 \pm 0,249^{\mathrm{a}}$ & $7,187 \pm 0,102^{\mathrm{b}}$ & $7,536 \pm 0,226^{\mathrm{b}}$ \\
$\operatorname{Al}\left(\mathrm{mm}^{2}\right)$ & $0,049 \pm 0,010^{\mathrm{a}}$ & $0,372 \pm 0,087^{\mathrm{b}}$ & $0,979 \pm 0,95^{\mathrm{c}}$ \\
$\operatorname{KMI}(\mathrm{mm})$ & $0,052 \pm 0,009^{\mathrm{a}}$ & $0,237 \pm 0,064^{\mathrm{b}}$ & $0,352 \pm 0,023^{\mathrm{c}}$ \\
\hline
\end{tabular}

$\mathrm{PLEI}$ = panjang lamina elastik interna; $\mathrm{Al}$ = area intima; $\mathrm{KMI}$ = ketebalan maksimum intima. Superskrip a, b, c antarkelompok respons berbeda secara signifikan $(p<0,05)$. 

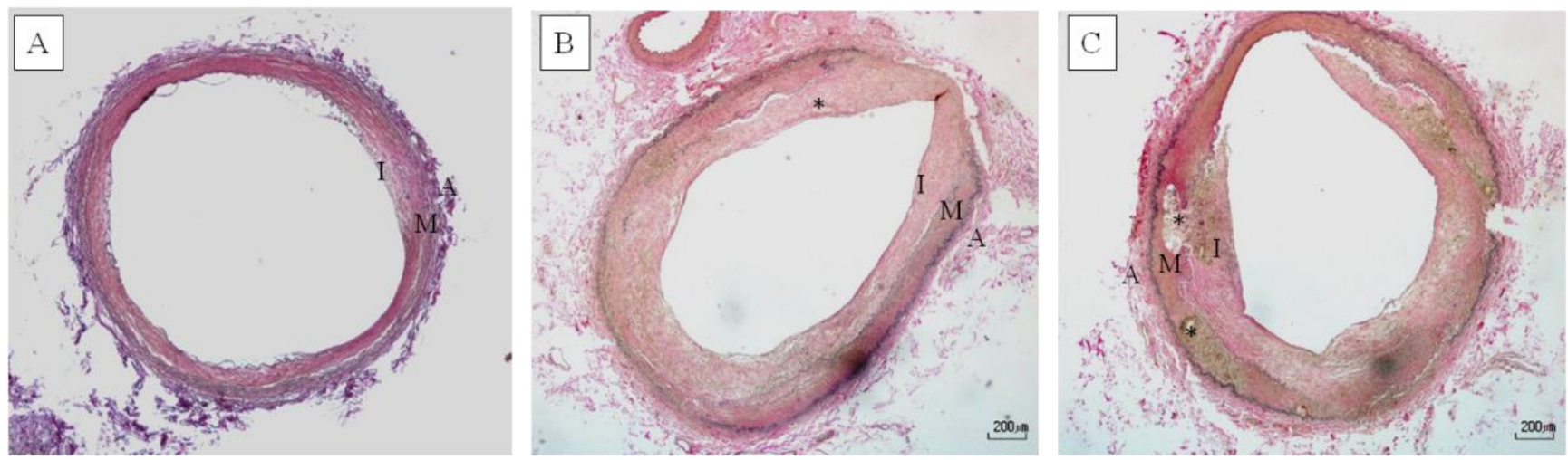

Gambar 1 Fotomikrograf arteri common iliak yang diwarnai dengan VVG. Gambar 1A menunjukkan lesio garit lemak, sedangkan Gambar 1B dan 1C menunjukkan lesio plak aterosklerosis dan penebalan tunika intima. Plak yang terbentuk pada Gambar 1B adalah ateroma yang dicirikan dengan terbentuknya pusat nekrosa (*), sedangkan pada Gambar $1 \mathrm{C}$ adalah fibroateroma yang dicirikan adanya kapsula fibrosa yang membatasi pusat nekrosa $\left({ }^{*}\right)$ dan lumen arteri. $A=$ hiporesponsif, $B=$ intermediet responsif, $C=$ hiper-responsif. $I=$ tunika intima, $M=$ tunika media, $A$ $=$ tunika adventisia. Bar $=200 \mu \mathrm{m}$.

\section{Area Lesio}

Hasil pengamatan area lesio disampaikan pada Tabel 2. Nilai PLEl common iliak paling kecil didapat pada kelompok hipo-responsif, namun tidak ada perbedaan nyata antara PLEI kelompok intermediet dan kelompok hiper-responsif $(P=0,239)$. Peningkatan PLEl adalah kompensasi akibat terbentuknya plak pada arteri. Nilai Al dan KMI paling tinggi diamati pada kelompok hiper-responsif diikuti kelompok intermediet dan hipo-responsif $(P<0,05)$. Nilai $\mathrm{Al}$ pada kelompok intermediet responsif dan hiper-responsif mencapai 7 dan 20 kali lipat dari Al pada kelompok hipo-responsif. Hal ini menunjukkan semakin tinggi kolesterol darah, semakin tebal lesio aterosklerosis yang terbentuk.

\section{PEMBAHASAN}

Kemunculan lesio aterosklerosis erat kaitannya dengan adanya berbagai faktor risiko. Laila et al. (2018) telah mengamati munculnya faktor-faktor risiko akibat perlakuan pakan aterogenik IPB-1, di antaranya, indeks masa tubuh untuk menilai obesitas, kolesterol darah untuk menilai hiperkolesterolemia, dan glukosa darah untuk menilai diabetes. Semua monyet pada penelitian ini tidak mengalami obesitas. Hal ini dinilai berdasarkan nilai indeks masa tubuh monyet yang berada dalam rentang normal. Selain itu, monyet juga tidak mengalami diabetes. Hal ini dilihat dari segi kadar glukosa darah. Akan tetapi, monyet pada penelitian ini menunjukkan faktor risiko berupa hiperkolesterolemia.
Beberapa varian pakan aterogenik IPB-1 sebelumnya juga telah dilaporkan dapat menginduksi hiperkolesterolemia pada hewan model MEP karena memiliki kandungan kolesterol, lipid, dan karbohidrat yang tinggi (Astuti et al., 2014). Griffin \& Lichtenstein (2013) menyatakan bahwa kolesterol tunggal tidak memiliki pengaruh signifikan pada peningkatan TPK pada manusia, namun perpaduan antara kolesterol dan karbohidrat tinggi pada makanan akan menaikkan kolesterol, terutama low density lipoprotein (LDL). Monyet pada penelitian ini menunjukkan adanya respons hipo dan hiper terhadap diet yang diberikan. Hal ini mirip dengan penelitian Clarkson et al. (1988) di mana MEP yang diberi western diet (mengandung $0,35 \mathrm{mg} / \mathrm{kal}$ kolesterol) juga menunjukkan adanya kelompok yang hipo-responsif (TPK $\pm 220 \mathrm{mg} / \mathrm{dl}$ ) dan hiper-responsif (TPK $\pm 420 \mathrm{mg} / \mathrm{dl})$. Hal yang berbeda pada penelitian ini adalah hewan diberi pakan dengan kandungan kolesterol yang tidak terlalu tinggi, yaitu 0,28-0,29 mg/dl sehingga juga menginduksi respons menengah, yang kemudian dimasukkan ke dalam kelompok intermediet responsif (Laila et al., 2018).

Plak aterosklerosis tidak teramati pada monyet hipo-responsif. Hal ini disebabkan karena TPK dan LDL kelompok ini masih dalam kisaran normal. Ratarata TPK normal MEP adalah $176 \mathrm{mg} / \mathrm{dl}$ (Aouidet et al., 1990). Nilai TPK normal pada MEP kelompok hiporesponsif sudah dilaporkan disebabkan oleh faktor genetik (Taher et al., 2016). Plak aterosklerosis ditemukan pada kelompok hewan intermediet dan hiper-responsif karena kondisi hiperkolesterolemia. Tingginya kolesterol meningkatkan kemungkinan ting- 
ginya LDL yang melintasi endotel dan masuk ke intima arteri. LDL akan merangsang sel-sel di intima untuk mensekresikan produk-produk oksidatif sehingga terjadi oksidasi LDL. Oksidasi LDL meliputi peroksidasi asam lemak pada fosfolipid, kolesterol ester, dan trigliserida. Fosfolipid yang teroksidasi merangsang sel endotel untuk menghasilkan molekul adhesi dan kemokin (Hansson \& Hermansson, 2011).

Molekul-molekul adhesi dan kemokin menyebabkan monosit dan limfosit direkrut ke ruang intima. Monosit yang berada pada intimal akan berubah menjadi makrofag, memakan LDL teroksidasi sehingga membentuk foam cell (Libby, 2002). LDL yang teroksidasi berat memiliki sifat toksik yang akan berimplikasi pada kematian sel dan pembentukan pusat nekrosis. Pusat nekrosis akan meluas dan berkembang sampai menjadi lesio aterosklerosis kompleks. Hasil pada penelitian ini menunjukkan lesio aterosklerosis kompleks ditemukan pada arteri common iliak kelompok intermediet dan hiper-responsif. Lesio kompleks inilah yang akan mengalami ruptur dan lepas membentuk trombus sehingga akan tersangkut dan menyumbat pembuluh darah yang lebih kecil (Sakakura et al., 2013). Penyumbatan pembuluh darah akan menyebabkan iskemia pada jaringan di sekitarnya dan menimbulkan gejala klinis PAD berupa rasa sakit yang amat sangat dan disfungsi ekstremitas (Criqui \& Aboyans, 2015).

Hasil penelitian ini menunjukkan area lesio mengalami perluasan seiring dengan peningkatan respons terhadap kolesterol. Pada pasien yang tidak menunjukkan gejala klinis PAD, area intima (lipid area) dilaporkan mencapai 20\% dari luas total arteri iliak (Nakamura et al., 2017). Area intima yang mengalami perluasan terus-menerus akan mempersempit lumen arteri dan menimbulkan stenosis. Stenosis pada arteri ekstremitas sering terjadi pada arteri iliak interna dan umumnya berasosiasi dengan stenosis pada arteri common iliak (Mahé et al., 2015).

Lesio yang terbentuk pada arteri common iliak MEP akibat induksi pakan aterogenik IPB-1 bervariasi antarsetiap grup respons. Lesio awal aterosklerosis terbentuk pada arteri kelompok hiporesponsif, sedangkan beberapa tingkatan plak hingga lesio yang kompleks terjadi pada arteri kelompok intermediet dan hiper-responsif. Semakin tinggi jumlah total plasma kolesterol, semakin luas dan tebal area lesio aterosklerosis yang terbentuk pada arteri common iliak. Dari keseluruhan hasil, plak aterosklerosis dapat terbentuk pada arteri iliak MEP yang diberi perlakuan pakan aterogenik IPB-1 dan berpotensi sebagai hewan model untuk penyakit PAD, kecuali kelompok hiporesponsif.

\section{UCAPAN TERIMA KASIH}

Penelitian ini didanai oleh Kementerian Riset, Teknologi, dan Pendidikan Tinggi melalui skim PMDSU. Penulis berterima kasih kepada Dr. Erni Sulistiawati sebagai ahli yang membantu dan mendampingi proses nekropsi di Pusat Studi Satwa Primata (PSSP) IPB. Terima kasih juga disampaikan kepada seluruh dokter hewan dan staf PPSP IPB dan Primate Reseach Center Wake Forest University, NCUSA atas bantuan dalam pengambilan data.

"Penulis menyatakan tidak ada konflik kepentingan dengan pihak-pihak yang terkait dalam penelitian ini".

\section{DAFTAR PUSTAKA}

Aouidet A, Bouissou $H$, de La Farge F, Valdiguié P. 1990. Serum reference values of the cynomolgus monkey, a model for the study of atherosclerosis. Journal of Clinical Chemistry and Clinical Biochemistry. 28:251-252.

Astuti DA, Sajuthi D, Suparto IH, Kaplan J, Appt S, Clarkson TB. 2014. The development of diets to induce atherogenic lipid profiles for cynomolgus monkeys in their country of origin. World Journal of Agricultural Research. 2:247-251.

Clarkson TB, Alexander NJ, Morgan TM. 1988. Atherosclerosis of cynomolgus monkeys hyper and hyporesponsive to dietary cholesterol: lack of effect of vasectomy. Arteriosclerosis. 8:488-498.

Criqui MH, Aboyans V. 2015. Epidemiology of peripheral artery disease. Circulation Resesrch. 116:1509-1526.

Fowkes FG, Rudan D, Rudan I, Aboyans V, Denenberg JO, McDermott MM, Norman PE, Sampson UK, Williams LJ, Mensah GA, Criqui MH. 2013. Comparison of global estimates of prevalence and risk factors for peripheral artery disease in 2000 and 2010: a systematic review and analysis. Lancet. 382:1329-1340.

Griffin JD, Lichtenstein AH. 2013. Dietary cholesterol and plasma lipoprotein profiles: randomizedcontrolled trials. Current Nutrition Report. 2: 274-282. 
Hansson GK, Hermansson A. 2011. The imune system in atherosclerosis. Nature Immnunollogy. 12:204-212.

Lawall H, Huppert P, Espinola-Klein C, Rümenapf G. 2016. The Diagnosis and treatment of peripheral arterial vascular disease. Deutsches Ärzteblatt International. 113: 729-736.

Laila SR, Astuti DA, Suparto IH, Handharyani E, Sajuthi D. 2018. Metabolic and Morphometric Changes in Indonesian Cynomolgus Monkeys (Macaca fascicularis) Fed an Atherogenic Diet Composed of Locally Sourced Ingredients. Veterinary World. 11 (11): 1609-1617.

Libby P. 2002. Inflamation in atherosclerosis. Nature. 420:868-874.

Mahé G, Kaladji A, Le Faucheur A, Jaquinandi V. 2015. Internal iliac artery stenosis: diagnosis and how to manage it in 2015. Frontiers in Cardiovascular Medicine. 2:1-9.

Nakamura E, Sato $\mathrm{Y}$, Iwakiri T, Yamashita A, Moriguchi-Goto S, Maekawa K, Gi1 T, Asada Y. 2017. Asymptomatic plaques of lower peripheral arteries and their association with cardiovascular disease: an autopsy study. Journal of Atherosclerosis Thrombosis. 24: 921-927.

Register TC, Appt SE, Clarkson TB. 2016. Atherosclerosis and vascular biologic responses to estrogen: histologic, immunohistochemical, biochemical, and molecular methods. In: Eysther KM (Ed). Estrogen reseptors: Methods and Protocols. Springer. New York (US): 517-532.
Sakakura K, Nakano M, Otsuka F, Ladich E, Kolodgie FD, Virmani R. 2013. Pathophysiology of atherosclerosis plaque progression. Heart Lung Circulation. 22: 399-411.

Shelton KA, Clarkson TB, Kaplan JR. 2012. Nonhuman Primate Models of Atherosclerosis. Dalam: Abee CR, Mansfield K, Tardif S, Moris T, (Eds). Non-Human Primate In Biomedical Research. Academic Pr. New York (US): 385-406.

Simionescu M, Sima AV. 2012. Morphology of atherosclerotic lesions. In: Inflammation and Atherosclerosis,Wick G, Grundtman C, (Eds.),. Springer-verlag. Wien: 19-37.

Stary $H C$, Chandler $A B$, Dinsmore RE, Fuster V, Glagov S, Insull W, Rosenfeld ME, Schwartz CJ, Wagner WD, Wissler RW. 1995. A definition of advanced types of atherosclerotic lesions and a histological classification of atherosclerosis. Circulation. 92: 1355-1374.

Stary HC, Chandler AB, Glagov S, Guyton JR, Insull W, Rosenfeld ME, Schaffer S, A Schwartz CJ, Wagner WD, Wissler RW. 1994. A definition of initial, fatty streak, and intermediate lesions of atherosclerosis; A report from the Committee on Vascular Lesions of the Council on Arteriosclerosis, American Heart Association. Circulation. 89: 2462-2478.

Taher A, Solihin DD, Sulistyani, Sajuthi D, Astuti DA. 2016. Genetic diversity within the 3'UTR of the cynomolgus macaque (Macaca fascicularis) LDLR Gene. IJSBAR. 26: 237-248. 